\title{
ВПЛИВ ЧАСТКИ СПАДКОВОСТІ ГОЛШТИНСЬКОЇ ПОРОДИ \\ ТА МЕТОДІВ ПІДБОРУ НА ГОСПОДАРСЬКИ КОРИСНІ ОЗНАКИ КОРІВ МОЛОЧНОЇ ХУДОБИ
}

\author{
Л. М. ХМЕЛЬНИЧИЙ, В. В. ВЕЧОРКА \\ Сумський нацуіональний аграрний університет (Суми, Украӥна) \\ khmelnychy@gmail.com
}

За очінкою корів української чорно-рябої молочної породи встановлено підвищення молочної продуктивності тварин за зростання частки умовної кровності голштина. Разом $з$ тим, на фоні поліпшення кількісних і якісних показників молока погіршується важливий показник відтворної здатності - сервіс-період. При дослідженні молочної продуктивності корів залежно від варіантів підбору виявлено перевагу тварин, отриманих від внутрішньо-лінійного розведення у порівнянні із кросом ліній.

Ключові слова: голштинська порода, підбір, надій, жир, білок, сервіс-період

THE EFFECT OF SHARE HEREDITABILITY OF HOLSTEIN BREED AND METHODS
FOR SELECTION OF ECONOMICALLY USEFUL TRAITS OF COWS DAIRY CATTLE L. M. Khmelnychyi, V. V. Vecherka

Sumy National Agrarian University (Sumy, Ukraine)

According to the estimates of cows of Ukrainian Black-and-White Dairy breed, an increase in the dairy productivity of cows has been found in the growth of the share of the conditional bloodiness of Holstein. At the same time, against the background of improving the quantitative and qualitative indicators of milk, has been deteriorated an important indicator of reproductive ability - service period. In the study of milk productivity of cows, depending on the selection options, has been revealed the advantage of animals obtained from intralinear breeding as compared to the cross of lines. Keywords: Holstein breed, selection, yield, fat, protein, service period

\section{ВЛИЯНИЕ ДОЛИ НАСЛЕДСТВЕННОСТИ ГОЛШТИНСКОЙ ПОРОДЫ И МЕТОДОВ ПОДБОРА НА ХОЗЯЙСТВЕННО ПОЛЕЗНЫЕ ПРИЗНАКИ КОРОВ МОЛОЧНОГО CКОТА}

\section{Л. М. Хмельничий, В. В. Вечёрка}

Сумский национальный аграрный университет (Сумыл, Украина)

По результатам оценки коров украинской чёрно-пестрой молочной породы установлено увеличение молочной продуктивности жсивотных при увеличении доли условной кровности голитина. Вместе с тем, на фоне улучшения количественных и качественных показателей молока ухудшается важный показатель воспроизводительной способности - сервис-период. При исследовании молочной продуктивности коров в зависимости от вариантов подбора выявлено преимущество животных, полученных от внутрилинейного разведения по сравнению с кроссом линий.

Ключевые слова: голштинская порода, подбор, удой, жир, белок, сервис-период

Упродовж тривалого часу в процесі створення нових порід молочної худоби проведено безліч досліджень 3 вивчення результатів схрещування місцевих порід з голштинськими плідниками. Результати щодо ефективності впливу спадковості голштинської породи на молочну продуктивність помісних корів на перших етапах схрещування порід істотно відрізнялись в залежності від умов паратипових чинників. Наразі із кожним наступним поколінням кровність 
корів молочної худоби за голштинською породою постійно зростає, спричиняючи неоднозначний ефект на показники молочної продуктивності та відтворної здатності тварин.

У цьому аспекті одними дослідниками повідомляється, що із нарощуванням спадковості голштина у корів української чорно-рябої молочної породи спостерігається зростання надою без змін або із незначним зниженням, а іноді із збільшенням жирномолочності $[1,10,20]$. Інші науковці стверджують, що із подальшим поглинанням чорно-рябої худоби голштинами надій і жирність молока у корів зменшується [8]. Окремими дослідниками $[4,14,18]$ також повідомляється про позитивний вплив спадковості голштинської породи на зростання надою без зміни якісних показників у корів чорно-рябої породи, проте іноді інтенсивність росту продуктивності при цьому є неоднаковою і знижується після досягнення тваринами кровності більше за $81-85 \%[1,22]$. Цими [8] та іншими $[5,11,17,19]$ дослідженнями виявлено, що на фоні збільшення молочної продуктивності, за зростання кровності голштина, погіршуються показники відтворної здатності, особливо збільшується сервіс-період.

Крім спадковості поліпшуючої породи на ефективність удосконалення стада на перспективу за ознаками молочної продуктивності істотним чином впливають методи підбору. Наразі за відсутності наукового супроводження селекційного процесу провідних племінних господарств науковими установами, закріплення плідників за стадами проводиться самими дилерами, головним завданням яких є уникнення спорідненого парування. Оскільки лінійне розведення потребує поглибленого вивчення та аналізу селекційної ситуації його застосовування обмежується окремими господарствами. Тому питання, який варіант підбору кращий: внутрішньо- чи міжлінійний не втрачає актуальності.

Ф. Ф. Ейснер [23] наголошував, що важливим джерелом отримання цінних племінних тварин при удосконаленні породи можуть бути кроси ліній, які дозволяють отримувати нові поєднання господарськи корисних ознак, так само як інтенсивне використання видатних плідників, їх синів та онуків у споріднених паруваннях. Звичайно, що цей процес має бути підконтрольним.

Про селекційну важливість та користь внутрішньолінійного розведення свідчить довготривала практика зоотехнії [3], тоді як аналіз наукових досліджень стосовно ефективності застосування кросу ліній носить суперечливий характер. Одні автори $[6,7,16]$ стверджують, що кращі результати за ознаками молочної продуктивності були отримані від міжлінійного підбору, а інші повідомляють, що не кожний крос дозволяє отримати позитивні результати, так само як і внутрішньолінійний підбір $[13,21]$, тому необхідно проводити оцінку на комбінаційну здатність генеалогічних формувань, використовуючи повторний підбір найкращих варіантів та відмовляючись від малоефективних.

Враховуючи важливий селекційний аспект щодо перспективи удосконалення високопродуктивного стада, вважаємо за доцільне дослідити залежність господарськи корисних ознак корів від частки спадковості голштинської породи та методів підбору.

Матеріали та методи досліджень. Наукові дослідження проведені у племінному заводі ТОВ агрофірми «Владана» Сумського району з розведення української чорно-рябої молочної та голштинської порід. Селекційна інформація отримана з бази даних первинного зоотехнічного та племінного обліку на основі системи СУМС “Інтесел Орсек”. Експериментальні показники опрацьовували методами біометричної статистики на ПК за формулами, наведеними Е. К. Меркурьевой [12].

Результати досліджень. Наразі тварини стада української чорно-рябої молочної породи племінного заводу агрофірми «Владана» на сто відсотків поглинуті спадковістю голштина. Ретроспективний аналіз ознак молочної продуктивності помісних за голштином корів засвідчив їхню залежність від спадковості поліпшувальної породи, табл. 1.

Розвиток української чорно-рябої молочної породи за принципом «відкритої популяції» з інтенсивним використанням чистопородних бугаїв-плідників голштинської породи зарубіжної селекції призвів до істотного зростання надою у корів. 


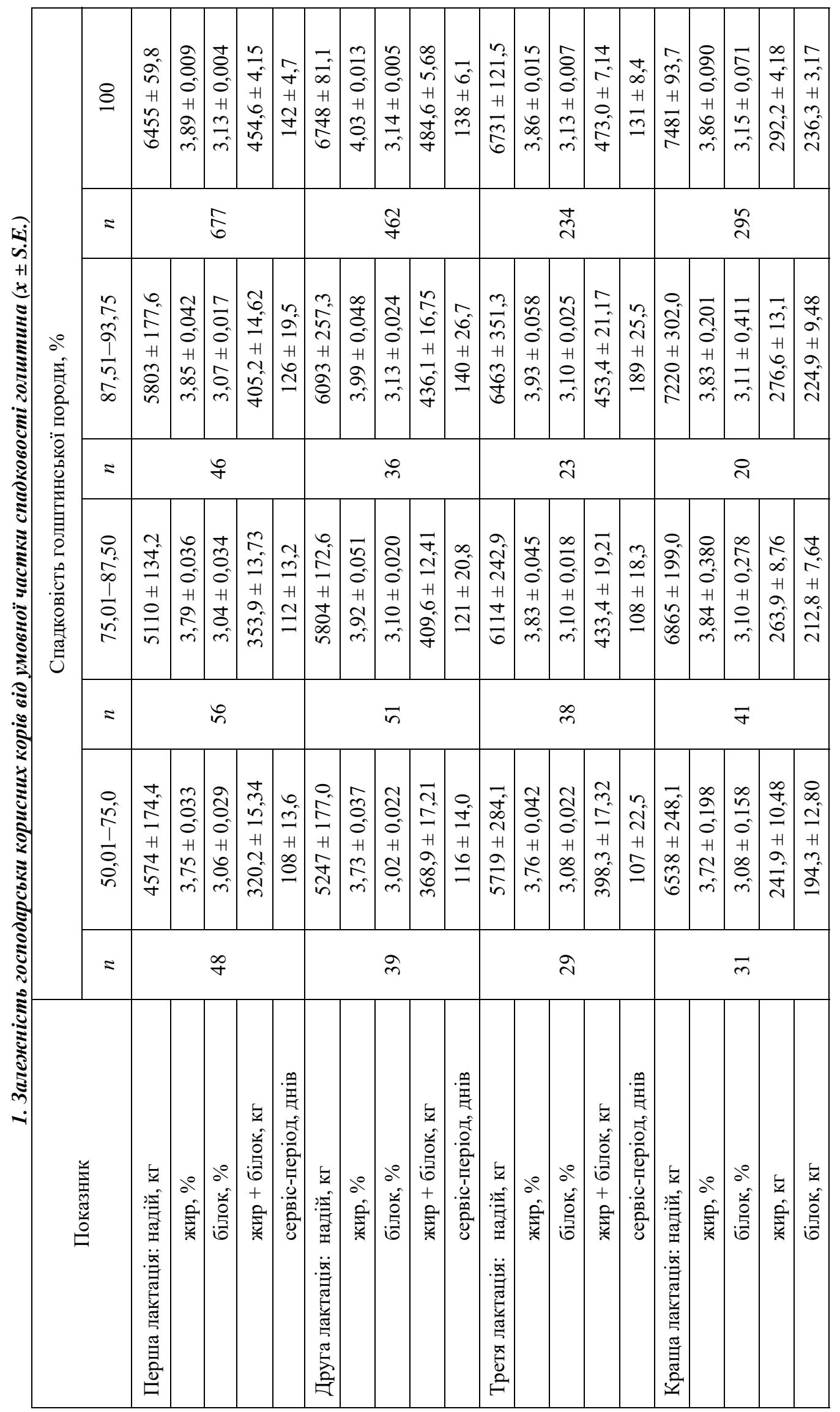


Оскільки генетичний потенціал продуктивності корів найкраще характеризує надій за кращу лактацію, порівняльний аналіз його величини засвідчив, що вищий показник надою за 305 днів отримано від чистопородних корів. Різниця на їхню користь у порівнянні з рештою груп корів виявилась 261-943 кг з достовірним підтвердженням у порівнянні з групами тварин, у яких кровність голштина становила 50,01-75,0 (P < 0,01) та 75,01-87,50\% (P < 0,001).

Підбір бугаїв з урахуванням племінної цінності з поліпшуючим ефектом за масовою часткою жиру їхнього потомства дозволив у процесі вбирного схрещування на лише утримати жирномолочність помісного поголів'я корів, а й навіть збільшити іiі на $0,14-0,27 \%$ водночас із зростанням надою. Масова частка жиру у групи низькокровних корів варіювала в залежності від лактації у межах 3,72-3,76\%, а у чистопородних голштинських тварин - відповідно 3,864,03\%. Нарощування спадковості голштинської породи не вплинуло на мінливість білка, масова частка якого становила у групи чистопородних корів 3,13-3,15\% залежно від лактації, що вище у порівнянні з низькокровними тваринами на 0,07-0,11\%.

Вбирне схрещування та інтенсивне використання генофонду голштинської породи має негативний вплив на показники відтворювальної здатності корів молочної худоби. Науковими дослідженнями встановлено, що за вбирного схрещування при зростанні рівня молочної продуктивності корів їхня відтворювальна здатність має тенденцію до погіршення $[2,8,9,15]$. Наведені авторами висновки підтверджуються результатами наших досліджень. Кращими показниками тривалості сервіс-періоду характеризувались корови з умовною кровністю за голштинською породою 50,01-75,0\% за даними усіх трьох лактацій порівняно із тваринами інших груп, у яких із зростанням спадковості голштинської породи аналогічно збільшувався сервіс-період. Найвищы показники сервіс-періоду з мінливістю тривалості у межах 126-189 та 131-142 дні виявились у корів з високою кровністю голштина 87,51-93,75\% та чистопородних голштинських тварин.

Порівняльний аналіз двох груп корів, одержаних від різних варіантів підбору, за ознаками молочної продуктивності (табл. 2) показав, що у даному господарстві лінійне розведення не практикується, оскільки кількість тварин у групі, отриманих від міжлінійного підбору, більша ніж у шість разів.

2. Показники молочної продуктивності корів за різних варіантів підбору $(x \pm$ S.E.)

\begin{tabular}{|c|c|c|c|c|}
\hline \multirow{2}{*}{ Показник } & \multicolumn{4}{|c|}{ Підбір: } \\
\hline & $n$ & внутрішньолінійний & $n$ & міжлінійний \\
\hline Перша лактація: надій, кг & \multirow{5}{*}{69} & $6436 \pm 164,3$ & \multirow{5}{*}{429} & $5847 \pm 70,1$ \\
\hline жир, \% & & $3,89 \pm 0,024$ & & $3,85 \pm 0,012$ \\
\hline білок, \% & & $3,13 \pm 0,020$ & & $3,10 \pm 0,006$ \\
\hline жир, кг & & $250,4 \pm 6,63$ & & $225,5 \pm 2,85$ \\
\hline білок, кг & & $202,6 \pm 5,32$ & & $186,9 \pm 2,35$ \\
\hline Друга лактація: надій, кг & \multirow{5}{*}{41} & $6516 \pm 266,3$ & \multirow{5}{*}{307} & $6165 \pm 88,1$ \\
\hline жир, \% & & $3,99 \pm 0,039$ & & $3,98 \pm 0,016$ \\
\hline білок, \% & & $3,14 \pm 0,023$ & & $3,13 \pm 0,007$ \\
\hline жир, кг & & $259,6 \pm 10,69$ & & $245,5 \pm 3,71$ \\
\hline білок, кг & & $204,3 \pm 8,40$ & & $197,0 \pm 3,07$ \\
\hline Третя лактація: надій, кг & \multirow{5}{*}{19} & $6309 \pm 462,1$ & \multirow{5}{*}{174} & $5808 \pm 123,8$ \\
\hline жир, \% & & $3,87 \pm 0,047$ & & $3,85 \pm 0,019$ \\
\hline білок, \% & & $3,12 \pm 0,022$ & & $3,10 \pm 0,010$ \\
\hline жир, кг & & $244,8 \pm 15,33$ & & $224,2 \pm 5,08$ \\
\hline білок, кг & & $201,1 \pm 14,31$ & & $180,6 \pm 4,61$ \\
\hline Краща лактація: надій, кг & \multirow{5}{*}{21} & $7658 \pm 296,9$ & \multirow{5}{*}{214} & $7094 \pm 99,0$ \\
\hline жир, \% & & $3,84 \pm 0,455$ & & $3,80 \pm 0,084$ \\
\hline білок, \% & & $3,14 \pm 0,387$ & & $2,53 \pm 0,302$ \\
\hline жир, кг & & $293,7 \pm 13,62$ & & $273,4 \pm 4,36$ \\
\hline білок, кг & & $240,5 \pm 9,77$ & & $224,2 \pm 3,52$ \\
\hline
\end{tabular}


Оцінка корів-первісток за молочною продуктивністю засвідчила достовірну перевагу групи корів, отриманих від внутрішньолінійного підбору над тваринами, отриманими від схрещування ліній. Високодостовірна перевага на їхню користь виявлена за величиною надою та загальним виходом молочного жиру і білка, яка відповідно становила 589 (Р < 0,001), 24,9 $(\mathrm{P}<0,001)$ та 15,7 кг $(\mathrm{P}<0,01)$.

Порівняльний аналіз підконтрольних груп корів за даними другої, третьої та кращої лактацій підтвердив кращі результати, отримані при внутрішньолінійному підборі, аналогічно за надоєм, загальним виходом молочного жиру та білка. Перевага за цими показниками збереглась у віці другої лактації з відповідною різницею, яка становила 351; 14,1 і 7,6 кг, третьої 501; 20,6 і 20,5 та кращої - 564; 20,3 і 16,3 кг. Попри переважаючу тенденцію корів, отриманих при внутрішньолінійному підборі, за ознаками надою, виходу молочного жиру та білка за даними оцінюваних лактацій, достовірна різниця підтверджена лише за надоєм кращої лактації при $\mathrm{P}<0,05$, оскільки за інтенсивного вибракування корів після першої лактації істотно зменшилась вибірка та збільшилась мінливість ознак.

Висновки. 1. За результатами вбирного схрещування корів української чорно-рябої молочної породи з голштинськими плідниками створене високопродуктивне стадо молочної худоби, яке наразі має статус племінного заводу з розведення голштинської породи.

2. Встановлено, що із зростанням умовної кровності голштинської породи покращуються ознаки молочної продуктивності та подовжується тривалість сервіс-періоду.

3. Найбільш ефективним за ознаками молочної продуктивності для даного стада виявився внутрішньолінійний підбір бугаїв-плідників у порівнянні з кросом ліній.

\section{БІБЛІОГРАФІЯ}

1. Аржанкова, Ю. В. Влияние голштинизации на основные хозяйственно полезные показатели высокопродуктивного черно-пестрого скота Псковской области / Ю.В.Аржанкова, Е. В. Лосякова, С. А. Попова // Известия Великолукской ГСХА. - 2016. - № 2. - С. 2-8.

2. Бойко, О. В. Методи поліпшення відтворювальної здатності молочної худоби за комплексом ознак в Черкаському регіоні : автореф. дис. ... канд. с.-г. наук : спец. 06.02.01 "Розведення та селекція тварин” / О. В. Бойко. - с. Чубинське Київської області, 2016. - 21 с.

3. Буркат, В. П. Розведення тварин за лініями: генезис понять і методів та сучасний селекційний контекст / В. П. Буркат, Ю. П. Полупан. - К. : Аграрна наука, 2004. - 68 с.

4. Влияние степени кровности на продуктивные показатели холмогорской и черно-пестрой породы / С. Е. Тяпугин, Н. И. Абрамова, Г. С. Власова, Л. Н. Богорадова // Сборник научых трудов Северо-Кавказского НИИЖ. - 2004. - Т. 2. - № 3. - С. 65-70.

5. Грачев, В. С. Возрастная динамика продуктивных и воспроизводительных качеств высокопродуктивного молочного скота / В. С. Грачев // Молочнохозяйственный вестник. - 2011. № 1. - С. 28-30.

6. Димчук, А. В. Молочна продуктивність корів подільського заводського типу української чорно-рябої молочної породи за різних варіантів підбору / А. В. Димчук // Розведення і генетика тварин: міжвід. темат. наук. зб. - К. : Аграрна наука. - 2008. - Вип. 42. - С. 55-62.

7. Ефименко, М. Я. Формирование внутрипородной структуры создаваемых пород молочного скота / М. Я. Ефименко // Технологія виробництва і переробки продукції тваринництва : зб. наук. пр. - Біла Церква. - 2010. - Вип. 3 (72). - С. 119-122.

8. Єфіменко, М. Перспективи розвитку української чорно-рябої молочної породи / М. Єфіменко, Б. Подоба, Р. Братушка // Тваринництво України. - 2014. - № 10. - С. 10-14.

9. Клопенко, Н. І. Ефективність вбирного схрещування у стадах української чорно-рябої молочної породи : автореф. дис. ... канд. с.-г. наук : спец. 06.02.01 "Розведення та селекція тварин” / Н. І. Клопенко. - с. Чубинське Київської області, 2016. - 20 с.

10. Клопенко, Н. І. Ефективність використання генофонду голштинської породи / Н. І. Клопенко // Збірник наукових праць Білоцерківського НАУ. - Біла Церква. - 2011. - Вип. 6 (88). C. 75-78. 
11. Кругляк, А. П. Методичні основи використання кросбридингу в молочному скотарстві / А. П. Кругляк // Розведення і генетика тварин : міжвід. темат. наук. зб. - 2016. - Київ. - Вип. 52. - C. 41-48.

12. Меркурьева, Е. К. Биометрия в селекции и генетике сельскохозяйственных животных // Е. К. Меркурьева. - М. : Колос, 1970. - 423 с.

13. Молочна продуктивність корів одержаних при внутрішньолінійному підборі та міжлінійних кросах / Л. М. Хмельничий, А. М. Салогуб, В. М. Бондарчук, А. П. Шевченко // Науково-теоретичний збірник Житомирського національного агроекологічного університету. ЖНАЕУ, 2015. - № 2 (52) - Т. 3 - C. 51-56.

14. Мымрин, В. С. Результаты голштинизации черно-пестрого скота в Уральском регионе / В. С. Мымрин, С. Л. Гридина, В. Ф. Гридин // Генетика и разведение животных. - 2014. - № 2. - C. 17-20.

15. Передрій, М. М. Каріотипова мінливість корів української червоно-рябої молочної породи 3 різним проявом репродуктивної функції : автореф. дис. ... канд. с.-г. наук : спец. 03.00.15 “Генетика" / М. М. Передрій. - с. Чубинське Київської області, 2018. - 21 с.

16. Петренко, I. П. Продуктивність корів від різних варіантів підбору в стадах новостворених молочних порід / І. П. Петренко, А. П. Кругляк, В. А. Цапко // Розведення і генетика тварин: міжвідомчий тематичний науковий збірник. - К. : Аграрна наука. - 2010. - Вип. 44. С. $143-145$.

17. Піддубна, Л. М. Голштинізація відкритої регіональної популяції чорно-рябої молочної худоби та перспективи іiі подальшого удосконалення / Л. М. Піддубна // Біологія тварин. 2014. - Т. 16, № 4. - С. 121-132.

18. Продуктивное использование и пожизненная молочная продуктивность коров разных генотипов / Н. А. Федосеева, 3. С. Санова, В. Н. Мазуров, М. С. Мышкина // Вестник Мичуринского государственного аграрного университета. - 2017. - № 1. - С. 43-47.

19. Решетникова, Н. Современное состояние и стратегия воспроизводства стада при повышении молочной продуктивности крупного рогатого скота / Н. Решетникова, Г. Ескин, Н. Комбарова // Молочное и мясное скотоводство. - 2013. - № 3. - С. 2.

20. Ставецька, Р. Молочна продуктивність української чорно-рябої молочної худоби: селекційні особливості / Р. Ставецька, І. Рудик // Тваринництво України. - 2011. - № 11. - С. 18 22.

21. Хмельничий, Л. М. Ефективність поєднання генеалогічних формувань в селекції молочної худоби / Л. М. Хмельничий, А. М. Салогуб // Збірник наукових праць Подільського державного аграрно-технічного університету. Серія “Технологія виробництва і переробки продукції тваринництва”. - Кам’янець-Подільський. - 2012. - Вип. 20. - С. 285-287.

22. Часовщикова, М. А. Молочная продуктивность черно-пестрого скота в зависимости от кровности по голштинской породе / М. А. Часовщикова // Вестник Алтайского государственного аграрного университета. - 2014. - № 8 (118). - С. 82-85.

23. Эйснер, Ф. Ф. Племенная работа с молочным скотом / Ф. Ф. Эйснер. - М. : Агропромиздат, 1986. - $182 \mathrm{c.}$

\section{REFERENCES}

1. Arzhankova, Ju. V., E. V. Losjakova, and S. A. Popova. 2016. Vlijanie golshtinizacii na osnovye hozjajstvenno poleznye pokazateli vysokoproduktivnogo cherno-pestrogo skota Pskovskoj oblasti - The influence of golshtinization on the fundamentally economically useful indicators of the highly productive Black-and-White cattle of the Pskov region. Izvestija Velikolukskoj GSHA - News Velikie Luki State Agricultural Academy. 2:2-8 (in Russian).

2. Boyko, O. V. 2016. Metody polipshennya vidtvoryuval'noyi zdatnosti molochnoyi khudoby za kompleksom oznak $v$ Cherkas'komu rehioni - Methods for improving the reproductive ability of dairy cattle for a set of traits in the Cherkassy region : avtoref. dys. ... na zdobuttya nauk. stupenya kand. 
s.-h. nauk : spets. 06.02.01 “Rozvedennya ta selektsiya tvaryn”. Chubynske Kyivskoi oblasti, 21 (in Ukrainian).

3. Burkat, V. P., and Yu. P. Polupan. 2004. Rozvedennya tvaryn za liniyamy: henezys ponyat' i metodiv ta suchasnyy selektsiynyy kontekst - Breeding of animals by lines: the genesis of concepts and methods, and modern selection context. Kyiv, Ahrarna nauka. 68 (in Ukrainian).

4. Tjapugin, S. E., N. I. Abramova, G. S. Vlasova, and L. N. Bogoradova. 2004. Vlijanie stepeni krovnosti na produktivnye pokazateli holmogorskoj i cherno-pestroj porody - Influence of the degree of kinship on the productive indicators of Kholmogory and Black-and-White breeds. Sb. nauch. tr. Severo Kavkazskogo NIIZh. - Collection of scientific works of the North Caucasian NIIZh. 2(3):6570 (in Russian).

5. Grachev, V. S. 2011. Vozrastnaja dinamika produktivnyh i vosproizvoditel'nyh kachestv vysokoproduktivnogo molochnogo skota - Age dynamics of productive and reproductive qualities of highly productive dairy cattle. Molochno hozjajstvennyj vestnik - Dairy economic bulletin. 1:28-30 (in Russian).

6. Dymchuk, A. V. 2008. Molochna produktyvnist' koriv podil's'koho zavods'koho typu ukrayins'koyi chorno-ryaboyi molochnoyi porody za riznykh variantiv pidboru - Dairy productivity of cows of Podilsky breed type of Ukrainian Black-and-White Dairy breeds for different variants of selection. Rozvedennya i henetyka tvaryn : mizhvidomchyy tematychnyy naukovyy zbirnyk. - Animal Breeding and Genetics, interdepartmental thematic scientific collection. Kyiv, Ahrarna nauka. 42:55-62 (in Ukrainian).

7. Efimenko, M. Ja. 2010. Formirovanie vnutriporodnoj struktury sozdavaemyh porod molochnogo skota - Formation of the intrabreed structure of dairy cattle breeds. Tekhnolohiya vyrobnytstva i pererobky produktsiyi tvarynnytstva - Technology of production and processing of livestock products. Bila Tserkva. 3(72):119-122 (in Russian).

8. Yefimenko, M. Ja., B. Podoba, and R. Bratushka. 2014. Perspektyvy rozvytku ukrayins'koyi chorno-ryaboyi molochnoyi porody - Prospects for development of Ukrainian Black-and-White Dairy breed. Tvarynnytstvo Ukrayiny - Animal husbandry of Ukraine. 10:10-14 (in Ukrainian).

9. Klopenko, N. I. 2016. Efektyvnist' vbyrnoho skhreshchuvannya u stadakh ukrayins'koyi chornoryaboyi molochnoyi porody : avtoref. dys. ... na zdobuttya nauk. stupenya kand. s.-h. nauk : spets. 06.02.01 "Rozvedennya ta selektsiyatvaryn" - The efficiency of absorbed crossing in the herds Ukrainian of Black-and-White Dairy breed : Author's abstract. dis. ... on obtaining sciences. degree of Cand. agricultural sciences : speciality 06.02.01 "Breeding and selection of animals". Chubynske Kyivskoi oblasti, 20 (in Ukrainian).

10. Klopenko, N. I. 2011. Efektyvnist' vykorystannya henofondu holshtyns'koyi porody - Efficiency of using the Holstein breed gene pool. Zbirnyk naukovykh prats' Bilotserkivs'koho NAU. Collection of scientific works of Bila Tserkva NAU. Bila Tserkva. 6(88):75-78 (in Ukrainian).

11. Kruhlyak, A. P. 2016. Metodychni osnovy vykorystannya krosbrydynhu v molochnomu skotarstvi - Methodical bases of using crossbreeding in dairy cattle. Rozvedennya i henetyka tvaryn - Breeding and genetics of animals. 52:41-48 (in Ukrainian).

12. Merkur'eva, E. K. 1970. Biometriya v selektsii i genetike sel'skokhozyaystvennykh zhivotnykh - Biometrics in the selection and genetics of farm animals. Moscov, Kolos, 423 (in Russian).

13. Khmel'nychyy, L. M., A. M. Salohub, V. M. Bondarchuk, and A. P. Shevchenko. 2015. Molochna produktyvnist' koriv oderzhanykh pry vnutrishn'o liniynomu pidbori ta mizhliniynykh krosakh - Milk productivity of cows obtained within intralinear selection and interlinear crosses. Naukovoteoretychnyy zbirnyk Zhytomyrs'koho natsional'noho ahroekolohichnoho universytetu. ZhNAEU Scientific and Theoretical Collection of Zhytomyr National Agroecological University. ZHNAEU. 2(52)3:51-56 (in Ukrainian).

14. Mymrin, V. S., S. L. Gridina, and V. F. Gridin. 2014. Rezul'taty golshtinizacii chernopestrogo skota $v$ Ural'skom regione - Results of golshtinization of Black-and-White cattle in the Urals region. Genetika i razvedenie zhivotnyh - Genetics and breeding of animals. 2:17-20 (in Russian). 
15. Peredriy, M. M. 2018. Kariotypova minlyvist' koriv ukrayins'koyi chervono-ryaboyi molochnoyi porody z riznym proyavom reproduktyvnoyi funktsiyi : avtoref. dys. ... na zdobuttya nauk. stupenya kand. s.-h. nauk : spets. 03.00.15 "Henetyka" - Karyotypic variability of cows of Ukrainian Red-and-White Dairy breed with different manifestation of reproductive function : Author's abstract of thesis on obtaining sciences degree of Candidate of agricultural sciences : speciality 03.00.15 "Genetics". Chubynske Kyivskoi oblasti, 21 (in Ukrainian).

16. Petrenko, I. P., A. P. Kruhlyak, and V.A. Tsapko. 2010. Produktyvnist' koriv vid riznykh variantiv pidboru $\mathrm{v}$ stadakh novostvorenykh molochnykh porid - Productivity of cows from different variants of selection in herds of newly created breeds. Rozvedennya i henetyka tvaryn : mizhvidomchyy tematychnyy naukovyy zbirnyk. - Animal Breeding and Genetics, interdepartmental thematic scientific collection. Kyiv, Ahrarna nauka. 44:143-145 (in Ukrainian).

17. Piddubna, L. M. 2014. Holshtynizatsiya vidkrytoyi rehional'noyi populyatsiyi chorno-ryaboyi molochnoyi khudoby ta perspektyvy yiyi podal'shoho udoskonalennya - Golshtinization of an open regional population of Black-and-White Dairy cattle and prospects for its further improvement. Biolohiya tvaryn - Biology of animals. 16(4):121-132 (in Ukrainian).

18. Fedoseeva, N. A., Z. S. Sanova, V. N. Mazurov, and M. S. Myshkina. 2017. Produktivnoe ispol'zovanie i pozhiznennaja molochnaja produktivnost' korov raznyh genotipov - Productive use and lifelong milk productivity of cows of different genotypes. Vestnik Michurinskogo gosudarstvennogo agrarnogo universiteta - Bulletin of Michurinsky State Agrarian University. 1:43-47 (in Russian).

19. Reshetnikova, N., G. Eskin, and N. Kombarova. 2013. Sovremennoe sostojanie i strategija vosproizvodstva stada pri povyshenii molochnoj produktivnosti krupnogo rogatogo skota - The current state and strategy of herd reproduction with increasing dairy productivity of cattle. Molochnoe $i$ mjasnoe skotovodstvo - Dairy and beef cattle breeding. (3):2 (in Russian).

20. Stavets'ka, R., and I. Rudyk. 2011. Molochna produktyvnist' ukrayins'koyi chorno-ryaboyi molochnoyi khudoby : selektsiyni osoblyvosti - Milk productivity of Ukrainian Black-and-White Dairy cattle : breeding features. Tvarynnytstvo Ukrayiny - Animal husbandry of Ukraine. 11(30):1822 (in Ukrainian).

21. Khmel'nychyy, L. M., and A. M. Salohub. 2012. Efektyvnist' poyednannya henealohichnykh formuvan' v selektsiyi molochnoyi khudoby - Effectiveness of the combination of genealogical formations in the dairy cattle selection. Zbirnyk naukovykh prats' Podil's'koho derzh. ahrarno-tekhnichnoho universytetu. Seriya "Tekhnolohiya vyrobnytstva i pererobky produktsiyi tvarynnytstva". Kam"yanets'-Podil's'kyy - Collection of scientific works of Podilsky State Agrarian-Technical University. Series "Technology of production and processing of livestock products". KamyanetsPodilsky. 20:285-287 (in Ukrainian).

22. Chasovshhikova, M. A. 2014. Molochnaja produktivnost' cherno-pestrogo skota v zavisimosti ot krovnosti po golshtinskoj porode - Dairy productivity of Black-and-White cattle depending on the degree of consanguinity by Holstein breed. Vestnik Altajskogo gosudarstvennogo agrarnogo universiteta - Bulletin of Altai State Agrarian University. 8(118):82-85 (in Russian).

23. Eysner, F. F. 1986. Plemennaya rabota s molochnym skotom - Breeding work with dairy cattle. Moscow, Agropromizdat, 184 (in Russian). 